\title{
An Analysis of the Ethics Infrastructure and Ethical Climate in Slovenian Public Administration
}

\author{
Janez Stare, Maja Klun
}

\begin{abstract}
In consideration of the fact that public administrations worldwide face a number of challenges, many governments are dedicated to improving the ethical climate in public administrations. The same issue is also the focus of the attention of many transnational associations. The basic goal is to ensure the development of comparable ethical climates, ethical behaviour in different public administrations and to develop comparable, suitable ethics infrastructures to enable this. Modern public administrations must bring ethical conduct to the fore and resist unethical behaviour. There are different ideas on how to build ethics infrastructures in public administrations, and examples of good practice that could facilitate the development of such infrastructures are found in the public and private sectors of different countries. In this paper, we connect ethics infrastructures and ethical climates. The evaluation of Slovenia's ethics infrastructures is based on the framework prepared by the OECD, using its questionnaire developed by Victor and Cullen. The results show that there is no general relationship between ethics infrastructures and ethical climates in public administrations. Nevertheless, some determinants of ethics infrastructures correlate to a high degree to the ethical climate, the strongest impact on ethics climates being the ethical infrastructure's determinant "public involvement and scrutiny".
\end{abstract}

\section{Keywords}

ethics infrastructure, ethical climate, public administration, Slovenia

\section{Introduction}

Public administration is a social subsystem significantly impacting on the functioning and development of society. With its position, role and competence, public 
administration directly or indirectly determines the principles of sound business, to which it is also subject. In public administration, work is defined with legality of conduct as its basic principle, but, in addition to this normative regulation, it is important to stress administrative ethics as the regulator and internal activator of the public official's conscience. The role of ethics in public administration is viewed in terms of ethical behaviour and ethical decision-making. Both are usually influenced by the ethics infrastructures and ethical climates in organisations. It is, arguably, important for public officials to behave ethically and to enhance their expertise and sense of responsibility and objectivity with regard to the ethical dimension: ethical decision-making is important for the credible functioning of public administrations.

Through the powers granted them, public officials make decisions. The role of ethics in decision-making is particularly prominent in cases where a specific dilem$\mathrm{ma}$ is not, as yet, defined in terms of legal regulations. This means that the legislator has not anticipated certain matters, issues or relationships. On the other hand, it is clear that it is impossible to define in advance every single relationship or state of being. In such cases, public officials are required to make decisions that are, to the best of their knowledge, based on the powers granted to them and in accordance with legislation. This means that they have to make a choice from two or more possible solutions, or to independently formulate the best solutions. Decisions that public officials are required to make based on their own consideration only serve to underline the significance of ethics in public administration. The issue of ethics in public administration is thus present on two levels. Firstly, there is the lack of the appropriate tools or instruments, the ethical infrastructure, to introduce ethics into the various bodies of public administration for the purpose of ensuring the ethical compliance of their operations, as well as preventing or reducing the unethical conduct of and in the public administration. The second issue lies in the lack of familiarity with the content, possibility and requirements of said tools and instruments the and lack of communicating encouragement in terms of putting these mechanisms into practice. There is much research that includes evaluations of the ethics climate in the private sector (e.g. Kish-Gephart et al. 2010; Victor and Cullen 1988), but these studies are mainly focused on the impact of the ethics climate on a range of factors of companies' operations (e.g. Babin et al. 2000; Moon and Choi 2014) and decisions in companies (Loe et al. 2000; O'Fallon and Butterfield 2005, Belak et al. 2014). There is less research that focuses on the evaluation of the ethics climate in the public sector (Ashkanasy et al. 2000; Bowman and Knox 2008; Vashdi et al. 2013; Raile 2013). When it comes to the public sector, ethics infrastructure is more often mentioned in literature (e.g. Parker et al. 2008; Fernández and Camacho 2015; OECD 1996). Despite various research related to the ethics climate and ethics infrastructure in the public sector, there is a lack of research trying to connect both of these elements (Vashdi et al. 2013; Vigoda-Gadot and Kapun 2005; GarciaSanchez et al. 2011; Bowman and Knox 2008). None of the research connects all 
elements of the ethics climate and infrastructure, so this is the main contribution of the presented research.

The main research question seeks the answer to whether there is a positive correlation between ethics infrastructures and ethical climates in public-administration organisations. We tried to determine how ethics infrastructures in public administrations function in practice. The paper is structured as follows: after the introduction, the ethical climate is explained, and its influence and importance in the public sector is presented together with field research; chapter two explains the ethics infrastructure and its role in terms of ethical behaviour; the final chapter presents the research methodology and results; the paper ends with conclusions.

\section{Ethical climates in public administration}

An ethical climate can be defined as the perception of what constitutes right behaviour and, thus, becomes a psychological mechanism through which ethical issues are managed (Martin and Cullen 2006, 177). Ethical climates are a subset of organisational work climates and also have a strong influence on several organisational outcomes. "Creating an ethical climate by enacting and enforcing codes of ethics, policies, and directives that specify, discourage, monitor, and correct unethical behavior has frequently been suggested as a means for curbing unethical behavior within the organisation" (Schwepken 2001, 48). Schwepken also finds that creating such a climate may have additional benefits, such as greater job satisfaction, stronger organisational commitment and, subsequently, lower turnover intentions.

Numerous researchers have since hypothesised that perceptions of ethical climates tap fundamentally into important issues for organisational participants that likely impact people's reactions to their work and their organisation (Martin and Cullen 2006, 180). "The prevailing perceptions of typical organisational practices and procedures that have ethical content constitute the ethical work climate, for example, when faced with a decision that has consequence for others, how does an organisational member identify the 'right' alternative in the organisation's view at least? An important source of this information are those aspects of the work climate that determine what constitutes ethical behavior at work" (Victor and Cullen 1988 , 101). By implementing and enforcing codes of ethics and policies on ethical behaviour, as well as rewarding ethical behaviour and punishing unethical behaviour, management can create an ethical climate that positively influences ethical behaviour in the organisation (Schwepken 2001, 41). Ethical climates influence both decision-making and behavioural responses to ethical dilemmas, which then go on to be reflected in various work outcomes (Simha and Cullen 2012, 20-21).

It seems that the creation of strong ethical climates, based on an ethical culture, strengthens ethical behaviour, limiting corruption and other violations (Amundsen and Pinto de Andrade 2009, Demmke and Moilanen 2011), one of the most impor- 
tant public-sector goals. The EU has introduced a variety of ethics instruments for curbing political and administrative corruption. Newly suggested instruments include: diversified rules, standards and codes; value management; ethical leadership; whistleblowing; disciplinary rules; job rotation; vulnerable-position risk analysis; training, including dilemma training; integrity plans; scandal management; audits; integrity officers; interest registers; transparency requirements; internet-based self assessments; and ethics-climate surveys. Demmke and Moilanen (2011, 121) emphasise that ethics instruments are more effective if they are implemented in a strong ethical climate.

The administrative work carried out by public officials is the core of their profession, intended for settling normative and administrative matters and connecting a variety of professional tasks to realise projected social goals. By preparing expert proposals for the decision-making process of the competent organs on one hand and implementing these decisions in real social life on the other, public officials directly involve themselves in social situations, introducing their professional views and subjective assessments regarding the regulation of normative contents. By doing so, they affect the content, the manner of regulating social relationships and the implementation of the constitution and legislation, as well as the protection of the legal system (Boštic 2000, 10).

Civil servants work in an ever-changing environment; on the one hand, there is increasing citizen demand, on the other, limitations are imposed by requirements to reduce public spending. This applies to financial, material and human resources. Civil servants assume responsibility for the ever increasing tasks resulting from the expansion of their competences, the increased market-orientation of the public sector and the responsibilities pursuant to new legislation.

The OECD has long expressed the great need to improve ethical conduct in terms of public service. In the document "Building Public Trust: Ethics Measures in OECD Countries", OECD member countries introduced significant management reforms which have changed the way the public sector operates (OECD PUMA 2000). It maintains that a cause for further concern is the apparent decline in confidence in the governments and public institutions of many countries and the implications this has for the legitimacy of government and public institutions. Weakening confidence is associated, at least in part, with revelations of inappropriate actions, in some cases outright corruption, on the part of public officials. Some remedial measures, broadly speaking, have the potential both to promote ethical behaviour and to prevent misconduct.

Menyah states $(2010,5)$ that some of the most common ethical dilemmas with which public servants are confronted revolve around aspects such as administrative discretion, corruption, nepotism, administrative secrecy, information leaks, public accountability and policy dilemma. According to Hanekom et al. (1990), the most common unethical problems in public sectors are: 
- bribery, nepotism and theft,

- conflicts of interest,

- misuse of insider knowledge,

- use and abuse of confidential information for personal purposes,

- public responsibility and accountability,

- corruption,

- the influence of interest and pressure groups, and so on.

The key objective is to support public officials in their pursuit of the highest standards of integrity and ethics in the rapidly changing environments of public sectors without weakening, destroying or undermining the main purpose of publicadministration reform, whose goal it is to improve effectiveness and performance. This could be achieved with the help of a good ethics infrastructure, declarations on values, such as codes of conduct, and professional socialisation activities, such as training and education.

"The ethical dilemma is to distinguish between what is right and what is wrong, and what seems to be right but is indeed wrong" (Gildenhuys 2004). The real problem in ethics management is not the lack of proper tools or instruments which managers should implement in their institutions in order to prevent or diminish unethical issues, but the lack of adequate communication and dissemination of these mechanisms; for example, we have codes of ethics, but in many cases, if you ask the employees or even the managers themselves, they do not know exactly where they can read these codes or what these codes really refer to (Puiu 2014, 606).

Despite the long-standing use of ethics codes, there is no dearth of ethical problems in government and private organisations. Ethical lapses make the news on a daily basis. When they occur in the public sector, they are not only news fodder but are likely to become major contributors to citizen distrust of government. The question, then, is what tools are available to help build or ensure ethical competence (Meine and Dunn 2013, 150).

Several research studies deal with different ethical-climate aspects, especially in the private sector. Victor and Cullen (1988) developed a framework for measuring ethical climates in organisations. Their framework is the most used in the field, being used by more than $75 \%$ of researchers. Later, the framework faced criticism from different fronts, and new frameworks were developed (i.e. Arnaud 2010, Kaptein 2008). Nevertheless, we decided to use Victor and Cullen's framework, pursuant to it allowing us to better compare our work with the majority of others. At the same time, researchers measuring ethical climates in the public sector usually use their framework. Rasmussen et al. (2003) use the framework to evaluate the difference in ethical climates between government and non-profit organisations. They found that public servant ethical climates are externally determined by professional or legal norms. Similarly, Raile (2013) suggests that "public servant perceptions of ethical climate have predictable sources." He pointed out that public administrators 
can simultaneously help shape ethical-climate perception. Shacklock et al. (2011) use the framework to test if similar dimensions, as determined in the framework, are relevant for the public sector. They conclude that there are several similarities, but they were unable to compare the proportion of variance explained by these five components.

\section{Ethics infrastructure}

An ethics infrastructure is a set of tools, processes, institutions and other mechanisms that contribute to the prevention of unethical conduct in a specific area of human activity, in an organisation, institution, etc. The phrase "ethical infrastructure" itself indicates that it is concerned with the basic foundation and tools for the practical implementation of ethics. Only a well-functioning ethical infrastructure encourages the desired behaviour of stakeholders. The term "ethical infrastructure" was originally coined in the United States to refer to policies and structures that support compliance with professional conduct rules (Parker et al. 2008, 163.)

The combination of ethical standard-setting, legal regulation and institutional reform is called "the ethics infrastructure" or "ethics regime" or "integrity system". Each part is a source of public-sector ethics; in other words, public-sector ethics emanate from several different sources. These sources range from the private ethical character of the individual public servant, via agency-internal regulations, the culture of the agency and national legislation to international conventions with written standards and codes of conduct. The most efficient ethics regime is when these three sources work in the same direction, in parallel. We will look at each of these sources of ethical conduct in the reverse order (Amundsen and Pinto de Andrade 2009, 13). An infrastructure approach implies a comprehensive view of ethics where the various elements complement each other holistically. They constitute a whole and need to function in harmony. Concentrating on one single element does not help (Focus 1998, 1).

Fernández and Camacho $(2015,3-5)$ summarise the elements that may contribute to ethics infrastructures (Table 1). They define three ethical-infrastrucure elements, the formal, the informal and leadership, and three goals, communication, training and management. 
Table 1

Summary of elements that may contribute to the ethics infrastructure

\begin{tabular}{|c|c|c|c|}
\hline \multirow{2}{*}{ Goals } & \multicolumn{3}{|c|}{ Elements } \\
\hline & Formal & Informal & Leadership \\
\hline Communication & $\begin{array}{l}\text { - Values, mission, } \\
\text { vision } \\
\text { - Code of ethics } \\
\text { - Code of conduct }\end{array}$ & $\begin{array}{l}\text { - Conversations } \\
\text { between employees } \\
\text { - Stories, myths } \\
\text { - Own language }\end{array}$ & $\begin{array}{l}\text { - Avoid "moral silence" } \\
\text { - Setting examples } \\
\text { - Establishing clear } \\
\text { expectations }\end{array}$ \\
\hline Training & $\begin{array}{l}\text { - Specific ethics } \\
\text { content } \\
\text { - Welcome } \\
\text { manual/process }\end{array}$ & - Socialisation process & $\begin{array}{l}\text { - Specific training for } \\
\text { managers on ethics } \\
\text { and Corporate Social } \\
\text { Responsibility }\end{array}$ \\
\hline Management & $\begin{array}{l}\text { - Ethical channel } \\
\text { - Sanction systems } \\
\text { - Self-evaluation } \\
\text { - Adherence to } \\
\text { bodies or standards } \\
\text { - Integrate ethical } \\
\text { issues into the } \\
\text { selection and } \\
\text { review process }\end{array}$ & $\begin{array}{l}\text { - Verbal and } \\
\text { nonverbal } \\
\text { behaviours } \\
\text { - Informal } \\
\text { performance rules } \\
\text { - Identify informal } \\
\text { leaders }\end{array}$ & $\begin{array}{l}\text { - Selection process } \\
\text { - Promote responsibility } \\
\text { of actions } \\
\text { - Recognise and reward } \\
\text { specific behaviours }\end{array}$ \\
\hline
\end{tabular}

Source: Fernández and Camacho 2015, 5.

Searching for answers on how to protect common values, international institutions have enhanced legal conventions and standards with their development and utilisation of ethical standards and ethics infrastructures, the provision of sample solutions for administration and control, thus forming the common foundation for the development of public ethics and integrity in member states; for instance, the OECD has prepared sample codes and proposals for structural measures, which serve as global guidelines for administration, resolution of ethical dilemmas and, consequently, the promotion of integrity in the different fields of the public and private sectors (Kečanovič 2012, 158).

Various studies address ethics infrastructure questions in different ways. The Office of Public Values and Ethics (2002) analysed individual aspects of ethics and ethical infrastructures in the public administrations of Australia, Canada, Denmark, the United States, New Zealand and the United Kingdom. It analysed the frameworks for the functioning and development of public administration (Statement of Values, Code of Conduct, Promotion of Values, Controlling Wrongdoing and Coordination and Evaluation). Based on research, an ethics infrastructure generally includes the following elements: a statement of values or principles, standards of conduct, tools to promote and raise awareness of values, control of wrongdoing and the management and evaluation of values and ethics programmes.

In 1996, PUMA (OECD 1996) identified factors affecting the standard of ethics and conduct in the public service and initiatives taken by governments to 
strengthen ethics-management frameworks. PUMA distilled from this the idea of an ethics "infrastructure" consisting of eight elements serving three functions that are capable of acting together to create an operating environment conducive to ethical conduct:

- political commitment;

- a legal framework;

- accountability mechanisms;

- codes of conduct or statements of values;

- professional socialisation;

- public-service conditions that are conducive to ethical behaviour;

- ethics co-ordinating bodies; and

- the public's involvement and scrutiny.

A well-functioning ethics infrastructure supports public-sector environments which encourage high standards of behaviour. Each function and element is a separate, important building block, but the individual elements should be complementary and mutually reinforcing. The elements need to interact to achieve the necessary synergy to become a coherent and integrated infrastructure. The elements of infrastructure can be categorised according to the main functions they serve - guidance, management and control - noting that different elements may serve more than one function (OECD PUMA 2000, 77). Guidance is provided by: a strong commitment of the political leadership; statements of values, such as codes of conduct; and professional socialisation activities, such as education and training. Management can be realised through the co-ordination by a special body or an existing central-management agency and through public-service conditions, management policies and practices. Control is primarily assured through a legal framework enabling independent investigation and prosecution, effective accountability and control mechanisms, transparency, public involvement and scrutiny. The ideal mix and degree of these functions will depend on the cultural and political-administrative milieu of each country.

Drawing on the experience of its member countries, the OECD has identified the institutions, systems, tools and conditions that governments use to promote ethics in the public sector: the necessary elements and functions of a sound ethics infrastructure (Bertok 1999, 1). A well-functioning Ethics Infrastructure supports a public-sector environment and encourages high standards of behaviour. Each function and element is a separate, important building block, but the individual elements should be complementary and mutually reinforcing. The elements must interact to achieve the necessary synergy to become a coherent and integrated infrastructure. The success of attempts to ensure better ethical environments depends on the proper management of entire ethics infrastructures (Focus 1998, 1). Larbi (2001) argues that political commitment to ethics reform is a key requirement for the effectiveness of other elements of the ethics infrastructure. 
There is also research on connecting ethical climates with public-organisation performance (Vashdi et al. 2013) and ethical climates and politics (Vigoda-Gadot and Kapun 2005). Nevertheless, research concerned with the influence of ethics infrastructures on ethical climates in public administration are rare, whilst in the private sector, we find several conclusions and results from a greater amount of research. One of the rare research studies concerning public administrations was carried out by Garcia-Sanchez et al. (2011). Their results are disappointing as they find that codes do not influence corruption problems in the public context, both in developed and developing countries. The most determing factor is the level of education in the control of corruption, especially in developing countries. Research that tries to connect one of the determinants of ethics infrastructures and ethical climates was carried out by Bowman and Knox (2008), who evaluated the contribution that ethics codes make to ethical climates. They found no positive relation.

\section{Research methodology and results}

Research was planned to be carried out in two stages. In the first stage, an evaluation of ethics infrastructures in public administrations was carried out. In the second stage, the influence of ethics infrastructures on civil-servant ethical climates was tested.

In the first stage, the evaluation of ethics infrastructure in public administration was carried out according to the eight elements determined by the OECD. Pursuant to the pair of elements consisting of three functions and two elements standing on their own (see OECD 1996, 6), we decided to evaluate each function utilising determined statements. For each function, we determined four factors/statements, two per element, and for each general element also four statements. We grade each statement from five points, meaning the statement stands in practice, to zero if it does not. The statements are presented in Table 2.

Our evaluation of ethical infrastructures was conducted in relation to middle and upper management in different types of public-sector organisations, such as Ministries, administrative units, local government, public institutions, and the like. We decided to survey management as they have a better overview of the determinants of ethics infrastructures, they can even partially influence elements and are the principle conduct supervisor. The statements were sent by e-mail to 400 managers' mail addresses: 20 request were rejected, so the sample consists of 380 managers. The reponse rate was low: only 64 managers from seven of the possible ten types of organisations provided evaluations. Consequently, our analysis is based on results from governmental offices, Ministries, administrative units, other Ministry units, regulatory bodies, other governmental offices and local government. 


\section{Table 2}

\section{Determinants for evaluation of ethics infrastructure}

\begin{tabular}{|c|c|c|}
\hline \multirow{8}{*}{ 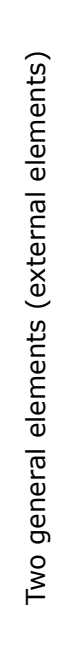 } & \multirow{4}{*}{$\begin{array}{l}\text { Political } \\
\text { commitment }\end{array}$} & $\begin{array}{l}\text { The leading political coalition expressed political commitment } \\
\text { through rhetoric (speeches, public announcements, written } \\
\text { statements by leaders). }\end{array}$ \\
\hline & & $\begin{array}{l}\text { Political commitment is usually demonstrated through setting } \\
\text { examples. }\end{array}$ \\
\hline & & $\begin{array}{l}\text { Political commitment is supported by allocating adequate } \\
\text { resources. }\end{array}$ \\
\hline & & $\begin{array}{l}\text { Elected officials can individually and as a group promote ethical } \\
\text { behaviour by serving as good role models. }\end{array}$ \\
\hline & \multirow{4}{*}{$\begin{array}{l}\text { Public } \\
\text { involvement } \\
\text { and scrutiny }\end{array}$} & $\begin{array}{l}\text { Access-to-information laws give the public an opportunity to act } \\
\text { as a watchdog over public officials. }\end{array}$ \\
\hline & & NGOs monitor ethical behaviour in public administrations. \\
\hline & & $\begin{array}{l}\text { For the public legislative framework, procedures and operating } \\
\text { principles are clear and understandable. }\end{array}$ \\
\hline & & $\begin{array}{l}\text { Public administration ensures the openness of its operations } \\
\text { (access to resources, to information). Ethics standards are } \\
\text { published. }\end{array}$ \\
\hline \multirow{4}{*}{ 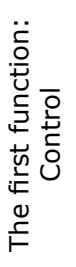 } & \multirow{2}{*}{$\begin{array}{l}\text { Legal } \\
\text { framework }\end{array}$} & $\begin{array}{l}\text { A legal framework adequately determines public servant } \\
\text { standards of behaviour. }\end{array}$ \\
\hline & & $\begin{array}{l}\text { A legal framework introducing new or strengthening existing } \\
\text { investigatory, prosecutory and other legal controls. }\end{array}$ \\
\hline & \multirow{2}{*}{$\begin{array}{l}\text { Accountability } \\
\text { mechanisms }\end{array}$} & Internal control mechanisms contribute to ethical behaviour. \\
\hline & & External control mechanisms contribute to ethical behaviour. \\
\hline \multirow{4}{*}{ 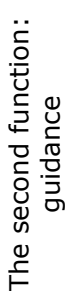 } & \multirow{2}{*}{$\begin{array}{l}\text { Codes of } \\
\text { conduct or } \\
\text { statements of } \\
\text { values }\end{array}$} & $\begin{array}{l}\text { General codes of ethics reflect the values, responsibilities and } \\
\text { principles of conduct of public officials. }\end{array}$ \\
\hline & & $\begin{array}{l}\text { The Code of Ethics is written in plain language and is consistent } \\
\text { with regulations in the field. }\end{array}$ \\
\hline & \multirow{2}{*}{$\begin{array}{l}\text { Professional } \\
\text { socialisation }\end{array}$} & $\begin{array}{l}\text { Employees are continuously trained on values and ethical } \\
\text { conduct. }\end{array}$ \\
\hline & & $\begin{array}{l}\text { Public-servant ethical behaviour is based on ethical leadership } \\
\text { exemplars. }\end{array}$ \\
\hline \multirow{4}{*}{ 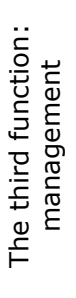 } & \multirow{2}{*}{$\begin{array}{l}\text { Public-service } \\
\text { conditions } \\
\text { (internal) }\end{array}$} & $\begin{array}{l}\text { Human resource policies promote ethics by ensuring the fair and } \\
\text { equitable treatment of employees. }\end{array}$ \\
\hline & & There are appropriate procedures for reporting wrongdoing. \\
\hline & \multirow{2}{*}{$\begin{array}{l}\text { Co-ordinating } \\
\text { body }\end{array}$} & $\begin{array}{l}\text { Parliamentary committees, central agencies and departments } \\
\text { promote and oversee ethics in the public service. }\end{array}$ \\
\hline & & $\begin{array}{l}\text { Best practice allows for the examination of ethical dilemmas and } \\
\text { provides advice as to how they should be resolved. }\end{array}$ \\
\hline
\end{tabular}

Source: own determinants using the OECD model

Pursuant to the evaluation of the ethics infrastructures of selected public bodies, the influence on civil-servant ethical climates was tested. As already mentioned, 
the evaluation of ethical climates was carried out using the questionnare developed by Victor and Cullen (1987). The questionnaire was sent to 1,030 public-body main-office e-mail addresses. The e-mail requested that responsible persons share the link to the questionnaire with their employees. Consequently, the total number of persons that actually received the information is unknown. According to the information generated from the web questionnaire, 2,059 people opened the link, but only 757 completed the questionnaire in full, with a further 460 doing so only partially. Our analysis is, therefore, based on results from 1,217 questionnaires.

Once we had collected the data, we sought evidence suggesting the influence of ethical infrastructures on ethical climates in the public sector. Statements in both questionnaires were evaluated using grades from one, the lowest grade, to five, the highest grade. We aggregated the means of each statement to seven groups according to organisational type and evaluated correlation using Pearson correlation coefficients. The Bonferroni Correction is used to counteract the problem of multiple comparisons. We interpret a very high correlation when the Pearson Correlation Coefficient is higher than 0.7 or a high correlation when the coefficient lies between 0.4 and 0.7 , these being commonly used measures in the field of social science.

In Table 3, we present the number of very high and high correlations from the twenty evaluated statements on ethics infrastructures and thirty-six statements on ethical climates.

As in previous research (Garcia-Sanchez et al. 2011), it is difficult to conclude that ethical infrastructures influence ethics climates in public organisations. Nevertheless, we can say that some functions and elements of the ethical infrastructure have extensive positive influence on the ethics climate in public organisations in Slovenia. It is obvious that some elements and functions play an important role on the ethics climate, since the highest number of high correlations are found for all statements in the element "Public involvement and scrutiny" and for determinants in two different functions: "Professional socialisation" in function guidance and "Public service conditions (internal)" in function management. In terms of the ethics climate, public involvement and other external controls play greater roles than the other determinants of the ethical infrastructure. A similarly positive correlation is also observed by Afedzie (2015). It is interesting that the statement "A legal framework adequately determines public servant standards of behaviour" did not even correlate with one statement in terms of the ethical climate. This is converse to the conclusions made by Bowman and Knox (2008) and Afedize (2015) and, to some extent, the research of Rasmussen et al. (2003) and Raile (2013). At the same time, the statements in relation to the ethical climate that are oriented towards "individualism" do not correlate with infrastructure. 


\section{Table 3}

The number of very high and high correlations between statements on ethical infrastructures and statements on ethical climates

\begin{tabular}{|c|c|c|c|}
\hline & & $\begin{array}{l}\text { very } \\
\text { high }\end{array}$ & high \\
\hline Q2a & $\begin{array}{l}\text { The leading political coalition expressed political commitment } \\
\text { through rhetoric (speeches, public announcements, written } \\
\text { statements by leaders). }\end{array}$ & 0 & 13 \\
\hline Q2e & $\begin{array}{l}\text { Political commitment is usually demonstrated through setting } \\
\text { examples. }\end{array}$ & 2 & 16 \\
\hline Q2h & Political commitment is supported by allocating adequate resources. & 10 & 11 \\
\hline Q20 & $\begin{array}{l}\text { Elected officials can individually and as a group promote ethical } \\
\text { behaviour by serving as good role models. }\end{array}$ & 0 & 11 \\
\hline Q2c & $\begin{array}{l}\text { A legal framework adequately determines public-servant standards } \\
\text { of behaviour. }\end{array}$ & 0 & 0 \\
\hline Q2f & $\begin{array}{l}\text { A legal framework introducing new or strengthening existing } \\
\text { investigatory, prosecutory and other legal controls. }\end{array}$ & 14 & 11 \\
\hline Q2i & $\begin{array}{l}\text { Access-to-information laws give the public an opportunity to act as a } \\
\text { watchdog over public officials. }\end{array}$ & 8 & 11 \\
\hline Q21 & $\begin{array}{l}\text { Public administration ensures the openness of its operations (access } \\
\text { to resources, to information). Ethics standards are published. }\end{array}$ & 9 & 19 \\
\hline Q2d & $\begin{array}{l}\text { For the public legislative framework, procedures and operating } \\
\text { principles are clear and understandable. }\end{array}$ & 3 & 24 \\
\hline Q2p & NGOs monitor ethical behaviour in public administrations. & 14 & 11 \\
\hline Q2g & $\begin{array}{l}\text { Parliamentary committees, central agencies and departments } \\
\text { promote and oversee ethics in the public administration. }\end{array}$ & 2 & 9 \\
\hline Q2m & $\begin{array}{l}\text { Best practice allows for the examination of ethical dilemmas and } \\
\text { provides advice as to how they should be resolved. }\end{array}$ & 10 & 10 \\
\hline Q2n & Internal control mechanisms contribute to ethical behaviour. & 12 & 12 \\
\hline Q2j & External control mechanisms contribute to ethical behaviour. & 0 & 15 \\
\hline Q2r & $\begin{array}{l}\text { General codes of ethics reflect the values, responsibilities and } \\
\text { principles of public official conduct. }\end{array}$ & 10 & 9 \\
\hline Q2b & $\begin{array}{l}\text { The Code of Ethics is written in plain language and is consistent with } \\
\text { regulations in the field. }\end{array}$ & 10 & 8 \\
\hline Q2s & Employees are continuously trained on values and ethical conduct. & 8 & 15 \\
\hline Q2k & $\begin{array}{l}\text { Public-servant ethical behaviour is based on ethical leadership } \\
\text { exemplars. }\end{array}$ & 7 & 21 \\
\hline Q2q & $\begin{array}{l}\text { Human-resource policies promote ethics by ensuring the fair and } \\
\text { equitable treatment of employees. }\end{array}$ & 11 & 12 \\
\hline Q2t & There are appropriate procedures for reporting wrongdoing. & 11 & 13 \\
\hline
\end{tabular}

For a better presentation of correlation, Figure 1 presents correlations between both groups of variables. Each point represents one variable statement, where black points represent ethics-infrastructure variables and white points ethical-climate 
variables (from Q2a to Q41, together with 36 statements from Victor and Cullen's model). Variables from both groups which have the highest Pearson correlation coefficients are seen closer together. $20 \%$ of the pairs with the highest correlation are connected by lines.

\section{Figure 1}

Correlation between ethics-infrastructure and ethical-climate variables

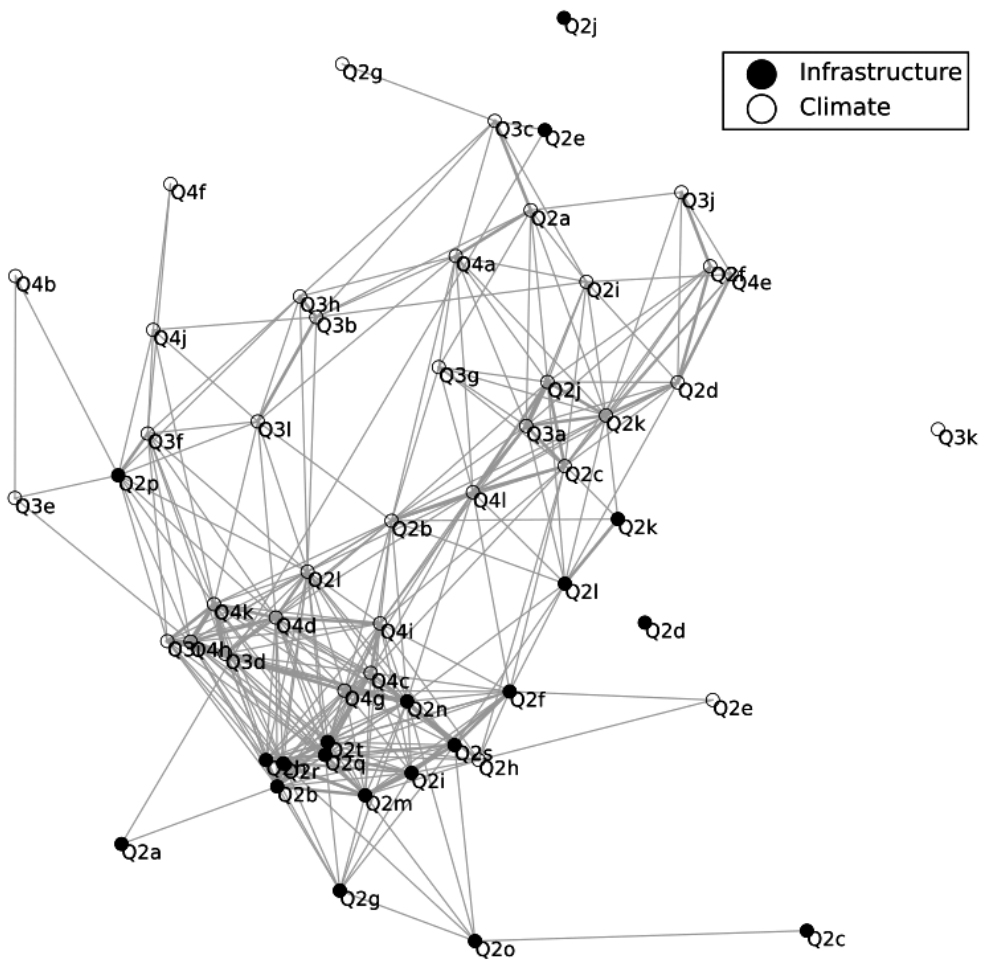

In the public sector, the importance of the political model and support for building ethics infrastructure and ethics action is often highlighted. It is interesting that the results of the research agree with this argument in part, when it comes to the impact of politics (through legislation) that allows openness of operation of the public administration, especially in terms of access to resources and the creation of an effective system of control, investigation and prosecution (sanctioning) of unethical behaviour. On the contrary, we can see that the respondents absolutely do not recognise the promotion of the construction of ethics climate through the behaviour model of the elected politicians. They also do not associate it with the functioning of the governing politics (in terms of expressing political support for ethical behaviour). 


\section{Conclusion}

The main purpose of this paper is to present ongoing research. We try to evaluate two key areas which directly influence personal ethical behaviour: ethics infrastructure and ethical climate. The evaluation of both was carried out using well-known models: the OECD's model of ethics infrastructures and Victor and Cullen's model for ethical climates. Consequently, in the next stages of research, comparisons with results from other researchers is possible. We are aware of our results' shortcomings; there are critics of both models. At the same time, the sample for the evaluation of the ethics infrastructure is relatively small and that is to be taken into account when interpreting results. Nevertheless, some conclusions can be drawn, and some implications are already felt in practice and evidenced in the literature. Further and more detailed analysis is still necessary and will be developed in the future, but the main purpose is achieved. We found that some ethical-infrastructure determinants influence the ethical climate in public organisations in Slovenia. Public involvement is given a very important role, which is not, as yet, sufficiently developed in countries with relatively short traditions in the field. The public, as a main controller of public-servant behaviour, seems to have a great influence on the ethics climate in Slovenia. It is difficult to conclude from previous research that this element is among the most important ones, as other research indicates that regulatory frameworks are more important. Such results can be partially influenced by what is current in terms of Slovenia's public administration, but can still be considered a situation different to countries with long traditions of public participation. This issue should be developed further. Simultaneously, it was, once again, proven that education on ethics is an important part of public-administration ethical climates. Similarly to other research, it could be concluded that, despite well developed ethics infrastructure, personal values are more important in determining ethical behaviour. Due to the fact that respondents highly connect the education of public officials with their ethical behaviour, we can conclude that respondents did not recognise the behaviour of elected politicants as an important factor of the ethical climate. As shown by the results, unethical behaviour in politics can be overcome by ethical leadership and permanent education in the field of values and ethical behaviour. The results emphasise the importance of good leadership. Therefore in the process of changing administrative culture to a better ethical climate, special emphasis should be put on leaders. In Slovenia, the legal framework is well developed and has been highly evaluated by respondents. It, therefore, puts greater emphasis on career and social development as well as internal control mechanisms. It would be interesting to find out if statements would be evaluated in the same way if the legal framework was not developed, or what would be the main reasons for such an evaluation. Therefore, there are enough challenges for further research. 


\section{References}

Afedize, R. H. 2015. Examing the Influence of Organizational Culture on Employees' Ethical Behavior in Public Sector Organizations. PhD thesis, College of Business and Technology, University of Texas at Tyler.

Amundsen, I. and V. Pinto de Andrade (eds). 2009. Public Sector Ethics. Compendium for teaching at the Catholic University of Angola (UCAN). Luanda: the Catholic University of Angola.

Arnaud, A. (2010). "Conceptualizing and Measuring Ethical Work Climate. Development and Validation of the Ethical Climate Index." Business \& Society 49(2), 345-358.

Ashkanasy, N. M., S. Falkus and V. J. Callan. 2000. "Predictors of Ethical Code Use and Ethical Tolerance in the Public Sector." Journal of Business Ethics 25(3), $237-253$.

Babin, B., J. S. Boles and D. P. Robin. 2000. "Representing the Perceived Ethical Work Climate among Marketing Employees." Journal of the Academy of Marketing Science 28(3), 345-358.

Belak J., J. P. Thommen and J. Belak. 2014. Integralni management in upravljanje: kultura, etika in verodostojnost podjetja. Maribor: Založba MER.

Bertok, J. 1999. "OECD Supports the Creation of Sound Ethics Infrastructure: OECD Targets Both the 'Supply Side' and the 'Demand Side' of Corruption." Public Personnel Management 28(4), 673-687.

Boštic, A. 2000. Upravna kultura in etika upravnega dela javnih uslužbencev. Modena: Grosuplje.

Bowman, J. S. and C. C. Knox. 2008. "Ethics in Government: No Matter How Long and Dark the Night." Public Administration Review 68(4), 627-639.

Demmke, C. and T. Moilanen. 2011. Effectiveness of Good Governance and Ethics in Central Administration: Evaluating Reform Outcomes in the Context of the Financial Crisis. Luxembourg: European Institute of Public Administration.

Fernández, J. L. and J. Camacho. 2015 [2005]. An Exploratory Study of SMEs in the Madrid Region. Dordrecht: Springer Science+Business Media. Available at URL (last accessed 6 September 2016).

Focus. 1998. Public Management Gazette 9.

Garcia-Sanchez, I. M., L. Rodriguez-Dominguez and I. Gallego-Alvarez. 2011. "Effectiveness of Ethics Codes in the Public Sphere: Are They Useful in Controlling Corruption?" International Journal of Public Administration 34(3), 190-195. doi: 10.1080/01900692.2010.532184. 
Gildenhuys, J. S. H. 2004. Ethics and Professionalism: The Battle against Public Corruption. Stellenbosch: Sun Press.

Hanekom, S. X. et al. 1990. Key Aspects of Public Administration. Johannesburg, South Africa: Southern Book Publishers.

Kaptein, M. 2008. "Developing and Testing a Measure for the Ethical Culture of Organizations: The Corporate Ethical Virtues Model." Journal of Organizational Behavior 29(7), 923-947.

Kečanović, B. 2012. "Na integriteti utemeljen odnos do skupnih vrednot." In B. Kečanović (ed.). Javna etika in integriteta: odgovornost za skupne vrednote: integriteta, odgovornost, vladavina prava. Ljubljana: Komisija za preprečevanje korupcije, 155-185.

Kish-Gephart, J. J., D. A. Harrison and L. K. Trevino. 2010. "Bad Apples, Bad Cases, and Bad Barrels: Meta-Analytic Evidence about Sources of Unethical Decisions at Work." Journal of Applied Psychology 95(1), 1-31.

Larbi, G. 2001. "Assessing Infrastructure for Managing Ethics in the Public Sector in Ethiopia: Challenges and Lessons for Reformers." International Review of Administrative Sciences 67(2), 251-262.

Loe, T. W., L. Ferrell and P. Mansfield. 2000. "A Review of Empirical Studies Assessing Ethical Decision Making in Business." Journal of Business Ethics 25(3), 185-204.

Martin, K. D. and J. B. Cullen. 2006. "Continuities and Extensions of Ethical Climate Theory: A Meta-Analytic Review." Joumal of Business Ethics 69, 175-194.

Meine, M. F. and T. P. Dunn. 2013. “The Search for Ethical Competency: Do Ethics Codes Matter?” Public Integrity 15(2), 149-166.

Menyah, D. 2010. Ethics, Ethical Dilemmas and the Public Service. CAPAM Featured Report: Ethical dilemmas in the public service. Ottawa: Commonwealth Association for Public Administration and Management.

Moon, H. K. and B. K. Choi. 2014. "How an Organization's Ethical Climate Contributes to Customer Satisfaction and Financial Performance: Perceived Organizational Innovation Perspective." European Journal of Innovation Management 17(1), 85-106.

OECD 1998. "Recommendation of the Council on Improving Ethical Conduct in the Public Service Including Principles for Managing Ethics in the Public Service". C(98)70/FINAL. Paris: OECD. Available at http://acts.oecd.org/ Instruments/ShowInstrumentView.aspx?InstrumentID=129\&Lang=en (last accessed 14 October 2016).

OECD. 1996. "Ethics in the Public Service: Current Issues and Practice." Public Management occasional papers 14. Paris: OECD. 
OECD PUMA. 2000. "Building Public Trust: Ethics Measures in OECD Countries". Available at http://www.oecd.org/gov/ethics/Principles-on-Managing-Ethics-in-the-Public-Service.pdf (last accessed 5 September 2016).

O'Fallon, M. J. and K. D. Butterfield. 2005. "A Review of the Empirical Ethical Decision-making Literature: 1996-2003." Journal of Business Ethics 59(4), 375-413.

Office of Public Values and Ethics. 2002. The Ethics Infrastructure in the Public Administration: The Experience of Several Countries. Ottawa: The Treasury Board of Canada Secretariat.

Parker, C., A. Evans, L. Haller, S. Le Mire and R. Mortensen. 2008. “The Ethical Infrastructure of Legal Practice in Larger Law Firms: Values, Policy and Behaviour." UNSW Law Journal 31(1), 158-188.

Puiu, S. 2014. Ethics Management in Public Sector - Background and Tools. $2^{\text {nd }}$ Global Conference on Business, Economics, Management and Tourism, 30-31 October 2014, Prague, Czech Republic.

Raile, E. D. 2013. "Building Ethical Capital: Perceptions of Ethical Climate in the Public Sector." Public Administration Review 73(2), 253-262.

Rasmussen, K., D. Malloy and J. Agarwal. 2003. "The Ethical Climate of Government and Non-profit Organizations: Implications for Public-Private Partnerships." Public Management Review 5(1), 83-97.

Schwepken, Jr., C. H. 2001. "Ethical Climate's Relationship to Job Satisfaction, Organizational Commitment, and Turnover Intention in the Salesforce." Journal of Business Research 54(1), 39-52.

Shacklock, A., M. Manning and L. Hort. 2011. "Dimensions and Types of Ethical Climate within Public Sector Human Resource Management." Journal of New Business Ideas \& Trends 9(1), 51-66.

Simha, A. and J. B. Cullen. 2012. "Ethical Climates and Their Effects on Organizational Outcomes: Implications from the Past and Prophecies for the Future." Academy of Management Perspectives 26(4), 20-34.

Vashdi, D. R., E. Vigoda-Gadot and D. Shlomi. 2013. "Assessing Performance: The Impact of Organizational Climates and Politics on Public Schools' Performance." Public Administration 91(1), 135-158. doi: 10.1111/j.14679299.2011.01968.x.

Victor, B. and J. B. Cullen. 1987. "A Theory and Measure of Ethical Climates in Organizations." Research in Corporate Social Performance and Policy 9, 51-71.

Victor, B. and J. B. Cullen. 1988. "The Organizational Bases of Ethical Work Climates." Administrative Science Quarterly 33(1), 101-125. 
The NiSPAcee Journal of Public Administration and Policy, Vol. IX, No. 2, Winter 2016/2017

Vigoda-Gadot, E. and D. Kapun. 2005. "Perceptions of Politics and Performance in Public and Private Organizations: A Test of One Model across Two Sectors." Policy and Politics 33(2), 251-276. 